\begin{tabular}{c|c|c}
\hline \hline & CLIMATE RESEARCH \\
Vol. 18: 105-112, 2001 & Clim Res & Published October 18 \\
\hline
\end{tabular}

\title{
Climate impacts on pioneer saltmarsh plants
}

\author{
Alan J. Gray*, Rebecca J. Mogg \\ Centre for Ecology \& Hydrology, Winfrith Technology Centre, Dorchester, Dorset DT2 8ZD, United Kingdom
}

\begin{abstract}
The 2 grass species that dominate the lower zones of North European saltmarshes utilise different photosynthetic pathways. Puccinellia maritima, a $\mathrm{C}_{3}$ species, occurs at higher elevations than Spartina anglica, a $\mathrm{C}_{4}$ species, which is a relatively recent invader and appears not to form extensive swards in latitudes north of $\sim 54^{\circ} \mathrm{N}$ because of the limiting effect of low early-season temperatures and the greater competitive ability of Puccinellia. We investigate the differential responses of the 2 grasses to rising temperatures and $\mathrm{CO}_{2}$ concentrations in the light of earlier work that predicts increases in their primary production, assuming a $3^{\circ} \mathrm{C}$ rise in temperature and a doubling of atmospheric $\mathrm{CO}_{2}$. Predictions of their responses to climate change are made using evidence from present day competitive interactions in relation to marsh elevation and latitude, and from a competition experiment in which the 2 species were grown under ambient and elevated temperature $\left(+3^{\circ} \mathrm{C}\right)$ and ambient and enriched $\mathrm{CO}_{2}(+340 \mathrm{ppm})$ in all factorial combinations. Puccinellia biomass was significantly increased, as expected, by $\mathrm{CO}_{2}$ enrichment and, probably from increasing early-season growth, by elevated temperature; the effect appeared additive, with the highest yield at the $+3^{\circ} \mathrm{C}$ +340 ppm treatment. Spartina growth increased as predicted in response to elevated temperature, but also unexpectedly in high $\mathrm{CO}_{2}$ treatment, possibly through increased efficiency in water-use. Competition was largely asymmetric in favour of Puccinellia, affecting Spartina height and shoot weight, with intraspecific effects on tiller production and total biomass; Spartina mainly responded to both treatments and competition by increased below-ground growth. These results are compared with other, single-factor, experiments and suggest that, depending critically on some other aspects of climate change such as rising relative sea level and nutrient dynamics, Spartina is likely to extend its range northwards as $\mathrm{CO}_{2}$ and temperatures rise, but Puccinellia will continue to replace it in the succession, and probably at lower marsh elevations than at present.
\end{abstract}

KEY WORDS: Spartina anglica $\cdot$ Puccinellia maritima $\cdot \mathrm{C}_{4}$ and $\mathrm{C}_{3}$ photosynthesis $\cdot$ Elevational niche - Competition $\cdot$ Elevated temperature and $\mathrm{CO}_{2}$ enrichment $\cdot$ Saltmarsh range extension

Resale or republication not permitted without written consent of the publisher

\section{INTRODUCTION}

The seaward edges of European temperate-zone saltmarshes are typically dominated by 2 widespread grass species, Puccinellia maritima (Huds.) Parl. and Spartina anglica C.E. Hubbard. Although annual plants of Salicornia and Suaeda species are common as pioneers, these 2 perennial grasses are the effective architects of saltmarsh development-their presence enhancing accretion and saltmarsh growth principally by preventing the resuspension of sediment delivered by the tides to the marsh (Gray et al. 1997, Brown 1998).

*E-mail: ajg@ceh.ac.uk
They can therefore be described as 'keystone' species, which bioengineer vast tracts of intertidal saltmarsh and have an important rôle in sea defences.

Puccinellia maritima (hereafter simply Puccinellia) is widespread in Europe, occurring to $70^{\circ} \mathrm{N}$ in Norway, and is also found on the southern coast of Greenland and in North America, where it may have been introduced (Gray \& Scott 1977). It is frequently the dominant plant over large areas of low and middle saltmarshes, especially those that are grazed or have had a history of grazing. Whereas the first record of PuCcinellia in the British Isles was in 1655 (Gray \& Scott 1977), Spartina anglica (hereafter Spartina) is by contrast known to have evolved around 1890 following 
hybridisation between the European $S$. maritima and the accidentally-introduced North American species $S$. alterniflora. The origin of this species on the English south coast and its subsequent spread around the world have been remarkably well documented (e.g. Lambert 1964, Marchant 1967, 1968, Ranwell 1967, Gray et al. 1991, Raybould et al. 1991a,b). An aggressive invader, it has come to occupy almost $25 \%$ of the saltmarsh in Britain (10000 ha of the 44000 ha surveyed by Charman 1990), and occurs in suitable habitats around the coast of Europe from 48 to $57.5^{\circ} \mathrm{N}$.

From the viewpoint of this paper, the most important contrast between the 2 species is that they utilise different photosynthetic pathways. Spartina is a $\mathrm{C}_{4}$ species, in which the first product of photosynthetic $\mathrm{CO}_{2}$ fixation is oxaloacetate instead of phosphoglycerate, as in $\mathrm{C}_{3}$ species. It is 1 of only 8 known $\mathrm{C}_{4}$ species in the UK, $\mathrm{C}_{4}$ photosynthesis being most common in semiarid tropical and subtropical species, and is only partially adapted to cooler climates (Long 1983). Field studies have shown that significant leaf canopy development does not begin in Spartina in south-east England until the mean air temperature exceeds $9^{\circ} \mathrm{C}$ (Dunn et al. 1981, Long 1983). Thus, low temperatures currently limit the plant's seasonal growth and productivity, and possibly its northward spread. Where water supply is not limiting, photosynthesis in $\mathrm{C}_{4}$ plants is $\mathrm{CO}_{2}$-saturated and therefore increases in atmospheric $\mathrm{CO}_{2}$ are unlikely to increase productivity through increased photosynthesis. However, higher atmospheric $\mathrm{CO}_{2}$ will increase photosynthesis in $\mathrm{C}_{3}$ plants such as Puccinellia, both under light-limiting and lightsaturating conditions, leading to increased productivity (Long 1983, 1990).

When considered in the context of currently predicted scenarios for global climate change, this differential response of Puccinellia and Spartina to elevated temperatures and atmospheric $\mathrm{CO}_{2}$, respectively, presents us with fascinating questions. If Spartina is able to profit from higher temperatures, particularly in the early spring, could it outcompete Puccinellia and other $\mathrm{C}_{3}$ species, extending its range within individual saltmarshes and estuaries and expanding its geographical range northwards? Equally, might the positive response of Puccinellia to $\mathrm{CO}_{2}$ enrichment allow it to retain a competitive advantage at higher elevations, where it currently replaces Spartina in the succession, and to prevent the northward invasion of Spartina?

In this paper we address these questions by examining the current interactions between Puccinellia and Spartina as revealed by their differential distribution in relation to saltmarsh elevation and latitude, we briefly describe a model by Long (1990) that predicts the impact of elevated temperature and $\mathrm{CO}_{2}$ on the 2 species separately, and we report the results of an ex- periment in which we have grown them in competition under conditions of both ambient and elevated temperature and $\mathrm{CO}_{2}$. Finally, we discuss the implications of these findings for future saltmarsh development.

\section{INTERACTIONS BETWEEN PUCCINELLIA AND SPARTINA}

\subsection{Elevational niches and competition}

Although other contributory factors were involved (e.g. vigorous vegetative growth, hybrid origin, extensive planting for mudflat stabilisation), the major reason for Spartina's successful invasion of large areas this century appears to be its ability to occupy mudflats to seaward of, and at lower elevations than, the previous lowest limit of perennial vegetation (usually Puccinellia) (Gray 1986, Gray et al. 1995). This has been demonstrated by measuring the upper and lower elevational limits - the elevational 'niche' — of a range of common saltmarsh species (Gray et al. 1991, 1995, Gray 1995). A summary of the results from a survey of 143 transects across saltmarshes in 28 estuaries on the south and west coasts of Britain is given in Fig. 1. The elevational niches of 6 common species are shown along a gradient of standardised marsh heights. The upper and lower limits for each species, on all transects where they are present, were recorded in metres above Ordnance Datum (Newlyn), with absolute height measured from nearby benchmarks, and related to local tidal levels to enable comparisons to be made between transects in terms of their tidal constants. Between 70 and $96 \%$ of the variance in the upper and lower limits, depending on the species, could be accounted for by a simple linear relationship

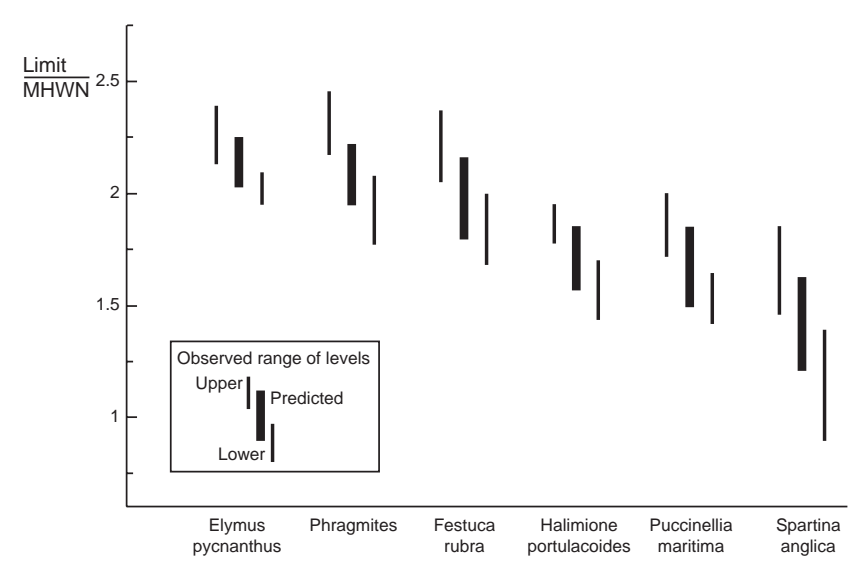

Fig. 1. Elevational ranges and variations in upper and lower limits (m OD) of 6 common saltmarsh plant species along a gradient of standard heights. Predicted range derived from linear regression with Mean High Water Neap tide level 
with Mean High Water Neap tide level. For Puccinellia and Spartina these were:

$$
\begin{aligned}
& \text { Puccinellia } \\
& \text { Upper limit }(\mathrm{m})=0.12+1.80 \mathrm{MHWN}\left(\mathrm{R}^{2}=89.5\right) \\
& \text { Lower limit }(\mathrm{m})=0.23+1.39 \mathrm{MHWN}\left(\mathrm{R}^{2}=92.3\right) \\
& \text { Spartina } \\
& \text { Upper limit }(\mathrm{m})=-0.21+1.71 \mathrm{MHWN}\left(\mathrm{R}^{2}=96.0\right) \\
& \text { Lower limit }(\mathrm{m})=-0.55+1.44 \mathrm{MHWN}\left(\mathrm{R}^{2}=95.5\right)
\end{aligned}
$$

The elevational niche of Spartina clearly extends below that of Puccinellia (Fig. 1) by an average of $68 \mathrm{~cm}$, an elevational niche that can include very extensive areas of shallow mudflats.

There is also niche overlap by $20 \mathrm{~cm}$ on average. The distribution of the 2 species within this overlap zone is likely to be determined principally by the outcome of interspecific competition. Scholten \& Rozema (1990) provided clear evidence of this in a field experiment in which either Spartina or Puccinellia were removed from subplots within 2 plots set out at slightly different elevations ( $\sim 4 \mathrm{~cm}$ difference, equivalent to 15 to $20 \mathrm{~min}$ difference in tidal submergence) in a community where the species were more-or-less homogeneously intermingled. When the regrowth was harvested after 3 mo it was shown that removal of Puccinellia caused a significant increase in Spartina biomass in the higher plot but not in the lower plot. Conversely, Spartina removal caused significant Puccinellia biomass increase in the lower but not the higher plot. This pattern of interactions points to the depression of Spartina by Puccinellia in the higher plot, with the reverse occurring in the lower plot. The outcome of interspecific competition is thus seen to be critically dependent on factors related to marsh elevation.

\subsection{Latitudinal variation}

The pattern of Spartina invasion varies with latitude. In the south of England and the south-west Netherlands, the rapid development of large, monospecific swards earlier this century has in several areas been followed by 'die-back', in which the swards break up and are replaced by mudflats. By contrast, in northern Britain (north of $\sim 54^{\circ} \mathrm{N}$ ) and in the Wadden Sea areas of The Netherlands and Germany, colonising Spartina is typically replaced by other species, including Puccinellia, at higher elevations. For example, in Morecambe Bay $\left(54^{\circ} 10^{\prime} \mathrm{N}\right)$ a major expansion began in the 1980s from only 2 clumps in 1968, and more than 100 ha of marsh originally formed by Spartina is now a mixed community dominated by Puccinellia in which Spartina is uncommon (Gray \& Raybould 1997). Although confounded by variation in substrate type, northern marshes being generally more sandy, it has been suggested that the latitudinal difference in marsh development is related to the effect of temperature on Spartina growth (Long et al. 1990, Scholten \& Rozema 1990, Gray et al. 1991).

This idea is supported by field measurements of the seasonal growth patterns in Spartina and Puccinellia in a marsh in east England $\left(52^{\circ} \mathrm{N}\right)$. Puccinellia increased shoot weight in March, when air temperatures rose above $5^{\circ} \mathrm{C}$, with growth peaking in June and July, whereas Spartina began to grow in May, when temperatures reached $9^{\circ} \mathrm{C}$, and peaked in October (Dunn et al. 1981, Long 1983). Thus, at higher latitudes Puccinellia can compete successfully with Spartina by earlier annual shoot development.

If the competitive interaction between Spartina and Puccinellia, or other species which replace Spartina as local elevation increases, is affected by temperature, especially spring temperatures, we would predict that the point at which Spartina is replaced on a given marsh would be further down the zone of niche overlap with other species the further north the marsh occurs. In fact, an earlier survey of the elevational niche of Spartina (Gray et al. 1991, Gray 1992) agrees with that prediction. The regression equation that best described the upper limit of Spartina was:

Upper limit $(\mathrm{m})=4.74+0.483(R)+0.068(F)-0.099(L)$

$$
\left(\mathrm{R}^{2}=90.2, \mathrm{SE}=0.50\right)
$$

where $R=$ Spring tide range $(\mathrm{m}), F=$ fetch in the direction of the transect $(\mathrm{km})$ and $L=$ latitude $\left(\right.$ decimal $\left.{ }^{\circ} \mathrm{N}\right)$. Thus, in marshes with a shorter seaward fetch Spartina extends further upshore than would be predicted from the effects of tidal range alone, but its upper limit occurs further downshore with increasing latitude.

\subsection{Long's predictive model}

In 1990, S. P. Long described a simple analytic model for predicting the primary production of Spartina and Puccinellia under conditions of elevated temperature and $\mathrm{CO}_{2}$ (Long 1990). The model is based on differences in solar radiation interception and conversion efficiencies, and was validated by comparing the hindcast and observed production for the 2 species on an east England marsh in 1978. The model was then used to predict the changes in the pattern of primary production to be expected in the year 2050, assuming a $3^{\circ} \mathrm{C}$ rise in temperature and doubling of atmospheric $\mathrm{CO}_{2}$.

Fig. 2 compares the model output for the 2 yr using daily values of solar radiation interception and conversion efficiency (variables and values given in Table 1 of Long 1990). Increases in annual productivity in 2050 are predicted for both species. Contributory factors 

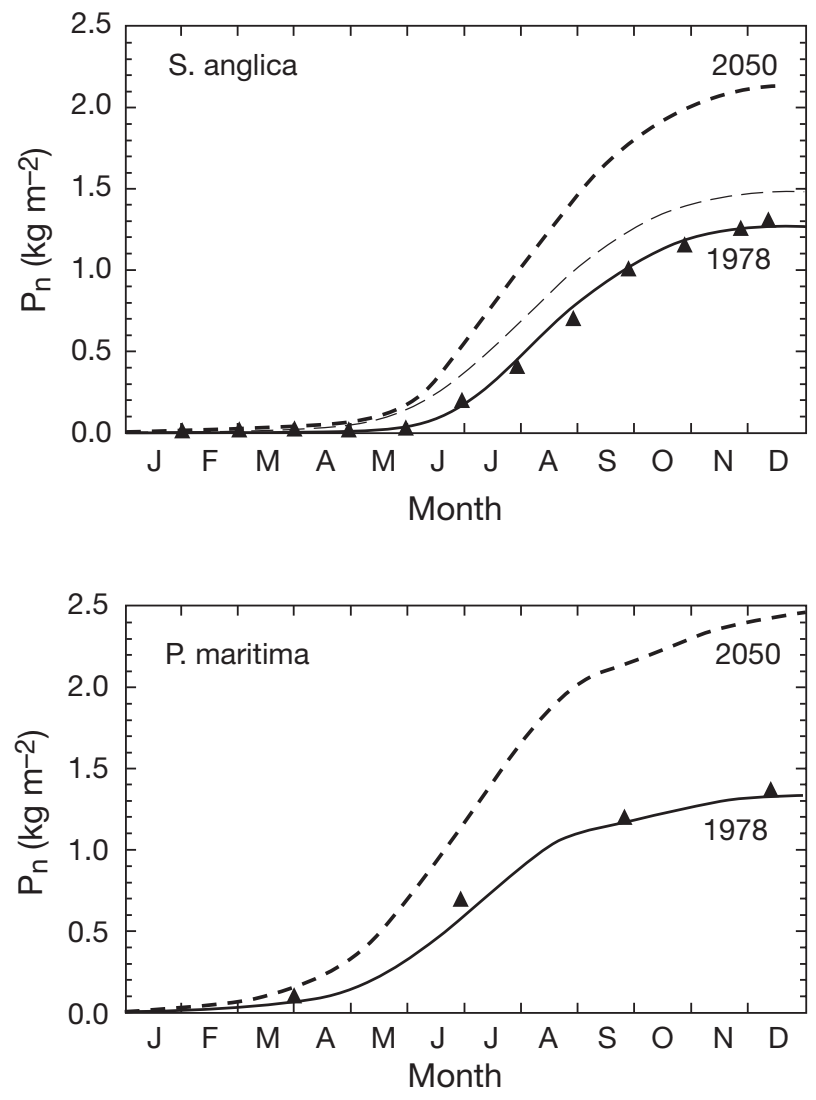

Fig. 2. Cumulative net primary production $\left(\mathrm{P}_{\mathrm{n}}\right)$ of Spartina and Puccinellia over 12 mo, predicted from changes in solar radiation and conversion efficiency and assuming a doubling of atmospheric $\mathrm{CO}_{2}$ in 2050 (from Long 1990). ( $\mathbf{\Delta}$ ) Net primary production for both species measured on an East Anglian saltmarsh in 1978. For Spartina, thin dashed line shows $\mathrm{P}_{\mathrm{n}}$ in 1978 if conversion efficiency assumed constant (as in $\mathrm{C}_{3}$ plants), rather than declining at temperatures $<12^{\circ} \mathrm{C}$ (bold dashed line)

include temperature-driven increases in leaf area, enabling the point where the leaf area index is sufficient to intercept $30 \%$ of the incoming radiation to be reached $35 \mathrm{~d}$ earlier in Puccinellia and $50 \mathrm{~d}$ earlier in Spartina. This would allow the latter's increased canopy size to capture and utilise high solar radiation input during May and June and, although gaining no direct benefit from higher $\mathrm{CO}_{2}$ levels, the predicted increase in annual net production is from $1.3 \mathrm{~kg} \mathrm{~m}^{2}$ in 1978 to $2.1 \mathrm{~kg} \mathrm{~m}^{2}$ in 2050. In Puccinellia the increase from $1.4 \mathrm{~kg} \mathrm{~m}^{2}$ to $2.5 \mathrm{~kg} \mathrm{~m}^{2}$ in the 2 years is due mainly to higher conversion efficiency in a high $\mathrm{CO}_{2}$ environment, although the model indicates that Puccinellia, too, will gain benefit from increased leaf growth in spring and autumn.

As Long (1990) acknowledges, the model ignores several factors that may change with climate and will affect conversion efficiency and growth. These include the effects of salinity, nutrient availability and water level changes which may change with rising relative sea levels. In addition, the model, of necessity, does not consider the changes when plants are grown in the presence of neighbours or, in particular, the competitive interactions between the 2 species. An experiment designed to measure these is described in the next section.

\section{A COMPETITION EXPERIMENT}

\subsection{Methods}

Plants of Puccinellia and Spartina were sampled from a saltmarsh at Kents Bank, Morecambe Bay $\left(54^{\circ} 10^{\prime} \mathrm{N}\right)$, where a relatively recent invasion by Spartina has led to the development, through successional displacement, of an extensive Puccinellia-dominated saltmarsh. Collected in May 1996, the plants were grown in the south of England in $15 \mathrm{~cm}$ diameter pots filled with John Innes No. 2 compost, initially in an unheated glasshouse and after $4 \mathrm{wk}$ in a gravel plunge bed. After 18 wk (October 1996), the growing plants were sampled at random to obtain 160 single-tiller units of each species for the experiment. Tillers were matched for initial size and established in pots of John Innes compost in a replacement series design (de Wit 1960), each series comprising 5 pots each with 4 tillers (4 Spartina, 3 Spartina + 1 Puccinellia, 2 Spartina + 2 Puccinellia, 1 Spartina +3 Puccinellia, and 4 Puccinellia). Eight series were set up in $22 \mathrm{~cm}$ diameter pots (low density) and 8 in $11 \mathrm{~cm}$ diameter pots (high density).

Following establishment for $3 \mathrm{wk}$, during which dead plants were replaced, the pots were transferred to the solardome facility at the Institute of Terrestrial Ecology, Bangor, North Wales $\left(53^{\circ} 10^{\prime} \mathrm{N}\right)$. The solardomes (Ashenden et al. 1994) comprise 8 hemispherical glasshouses in which atmospheres are controlled with a high degree of precision to provide 2 levels of temperature (ambient and $+3^{\circ} \mathrm{C}$ tracked continuously above ambient) and $2 \mathrm{CO}_{2}$ concentrations (ambient and ambient $+340 \mathrm{ppm} \mathrm{CO}_{2}$ ). The 8 domes provide 2 replicates for each temperature $\times \mathrm{CO}_{2}$ combination (ambient temperature + ambient $\mathrm{CO}_{2}$, elevated temperature + ambient $\mathrm{CO}_{2}$, ambient temperature + elevated $\mathrm{CO}_{2}$, and elevated temperature and elevated $\mathrm{CO}_{2}$ ). A single series of each pot size was placed in each dome and maintained with non-limiting water supplies and a single addition after 20 wk of generalpurpose fertiliser $(14 \mathrm{~N}: 10 \mathrm{P}: 27 \mathrm{~K})$, before harvesting in September 1997, after 11 mo growth. At harvest, each plant was separated into above- and below-ground material, washed and dry weighed for $2 \mathrm{~d}$ at $80^{\circ} \mathrm{C}$ before scoring for variation in yield. A summary of the results is given below. 
Table 1. Individual plant means of 6 yield variables at final harvest in solardome experiment. Treatments $\left(2\right.$ domes treatment $\left.^{-1}\right)$ were: Amb. = ambient temperature, $\mathrm{CO}_{2}$ tracked to outside $;{ }^{\circ} \mathrm{C}=+3^{\circ} \mathrm{C}$, ambient $\mathrm{CO}_{2 i}+\mathrm{CO}_{2}=$ ambient temperature, 340 ppm $\mathrm{CO}_{2}$ increase above ambient $;++=3^{\circ} \mathrm{C}$ increase, $340 \mathrm{ppm} \mathrm{CO}$ increase. Significance levels from generalised ANOVA, of log transformed values, in which density = effect of pot size (1 df), PPucc = effect of proportion of Puccinellia ( $3 \mathrm{df}), \mathrm{CO}_{2}=$ effect of elevated CO${ }_{2}(1 \mathrm{df})$, and

$\mathrm{T}=$ effect of elevated temperature (1 df). Significance ${ }^{*} \mathrm{p}<0.05,{ }^{* *} \mathrm{p}<0.01,{ }^{* * *} \mathrm{p}<0.001$. ns, no significant effects detected

\begin{tabular}{|c|c|c|c|c|c|c|}
\hline Trait & Species & Amb. & $+{ }^{\circ} \mathrm{C}$ & $+\mathrm{CO}_{2}$ & ++ & Significant main effects \\
\hline $\begin{array}{l}\text { Tiller } \\
\text { number }\end{array}$ & $\begin{array}{l}\text { Spartina } \\
\text { Puccinellia }\end{array}$ & $\begin{array}{r}4.10 \\
31.46\end{array}$ & $\begin{array}{r}6.17 \\
17.69\end{array}$ & $\begin{array}{r}6.00 \\
25.76\end{array}$ & $\begin{array}{r}3.48 \\
25.98\end{array}$ & $\begin{array}{l}\text { Density* }{ }^{*}, \mathrm{CO}_{2} \times \mathrm{T}^{*} \\
\text { PPucc }^{* *}, \mathrm{CO}_{2} \times \mathrm{T} \times \text { Density }^{*}, \mathrm{CO}_{2} \times \mathrm{T} \times \text { PPucc }^{*}\end{array}$ \\
\hline $\begin{array}{l}\text { Flowering } \\
\text { tillers }\end{array}$ & $\begin{array}{l}\text { Spartina } \\
\text { Puccinellia }\end{array}$ & $\begin{array}{l}0.13 \\
1.79\end{array}$ & $\begin{array}{l}0.11 \\
0.42\end{array}$ & $\begin{array}{l}0.28 \\
1.34\end{array}$ & $\begin{array}{l}0.01 \\
1.53\end{array}$ & $\begin{array}{l}\text { ns } \\
\text { Density }{ }^{* *}, \text { Density } \times \text { PPucc }^{*}\end{array}$ \\
\hline $\begin{array}{l}\text { Plant } \\
\text { height }(\mathrm{cm})\end{array}$ & $\begin{array}{l}\text { Spartina } \\
\text { Puccinellia }\end{array}$ & $\begin{array}{l}15.37 \\
44.47\end{array}$ & $\begin{array}{l}16.69 \\
44.08\end{array}$ & $\begin{array}{l}19.98 \\
48.24\end{array}$ & $\begin{array}{l}17.88 \\
54.98\end{array}$ & $\begin{array}{l}\text { PPucc }^{*} \\
\text { Density }\end{array}$ \\
\hline $\begin{array}{l}\text { Shoot } \\
\text { weight }(\mathrm{g})\end{array}$ & $\begin{array}{l}\text { Spartina } \\
\text { Puccinellia }\end{array}$ & $\begin{array}{l}0.45 \\
1.77\end{array}$ & $\begin{array}{l}0.70 \\
1.28\end{array}$ & $\begin{array}{l}0.89 \\
1.61\end{array}$ & $\begin{array}{l}0.37 \\
2.70\end{array}$ & $\begin{array}{l}\text { Density }{ }^{*}, \mathrm{PPucc}^{*}, \mathrm{CO}_{2} \times \mathrm{T}^{*}, \mathrm{CO}_{2} \times \mathrm{T} \times \text { Density }^{* *} \\
\text { Density }\end{array}$ \\
\hline $\begin{array}{l}\text { Below-ground } \\
\text { weight }(\mathrm{g})\end{array}$ & $\begin{array}{l}\text { Spartina } \\
\text { Puccinellia }\end{array}$ & $\begin{array}{l}0.61 \\
0.42\end{array}$ & $\begin{array}{l}0.97 \\
0.24\end{array}$ & $\begin{array}{l}1.38 \\
0.36\end{array}$ & $\begin{array}{l}0.60 \\
0.37\end{array}$ & $\begin{array}{l}\mathrm{CO}_{2} \times \mathrm{T}^{*}, \mathrm{CO}_{2} \times \mathrm{T} \times \text { Density }^{* *} \\
\mathrm{CO}_{2} \times \mathrm{T} \times \mathrm{PPuCC}^{* *}\end{array}$ \\
\hline $\begin{array}{l}\text { Total bio- } \\
\text { mass }(g)\end{array}$ & $\begin{array}{l}\text { Spartina } \\
\text { Puccinellia }\end{array}$ & $\begin{array}{l}1.04 \\
2.19\end{array}$ & $\begin{array}{l}1.67 \\
1.53\end{array}$ & $\begin{array}{l}1.98 \\
1.97\end{array}$ & $\begin{array}{l}0.97 \\
3.08\end{array}$ & 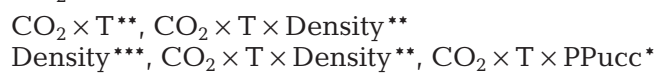 \\
\hline
\end{tabular}

\subsection{Results}

A general analysis of variance in 6 yield parameters (Table 1) was performed to reveal main effects within the experiment. Those aspects of yield significantly affected by competition were detected by analysing the source of variation due to the proportion of Puccinellia in the mixtures, the term 'PPucc' in Table 1. (For Spartina this is $0,25,50$ or $75 \%$, and for Puccinellia $100,75,50$ or $25 \%$.)

The significant effect of density on most variables reflects the importance of differences in the resources available in the different soil volumes and underlines the importance of varying density in such experimental designs (see Section 3.3). However, final yield (biomass) in both species was significantly affected by treatment, either by the interaction between $\mathrm{CO}_{2}$ level and temperature or the interaction between these treatments and density. The biomass of Puccinellia was also affected by the interaction between $\mathrm{CO}_{2}$ level, temperature and competition. The competition on inspection was seen to be intraspecific, with average yields of 5.30 and $5.19 \mathrm{~g}$ in $+3^{\circ} \mathrm{C}$ and enriched $\mathrm{CO}_{2}$ treatments, respectively, when grown with 3 Spartina plants, compared with 1.63 and $2.60 \mathrm{~g}$ in those treatments when grown with 3 other Puccinellia plants.

In most cases where an interaction effect was detected, Puccinellia was the superior competitor, exerting a significant negative effect on the height and above-ground weight of Spartina, as well as demonstrating intraspecific competition for tiller number and total biomass. However, the effects on Puccinellia root growth appear difficult to interpret. Intraspecific competition is indicated by increasing root weight in pots with fewer Puccinellia plants in ambient conditions
(0.37 $\mathrm{g}$ in pots with 4 Puccinellia to $0.98 \mathrm{~g}$ in pots with only 1 Puccinellia) and in domes with both elevated temperature and enriched $\mathrm{CO}_{2}(0.29$ to $0.72 \mathrm{~g})$. In the treatments with either elevated temperature or enriched $\mathrm{CO}_{2}$ alone, however, the effect was reversed, with lower mean root weights in Puccinellia plants competing with 3 Spartina plants than in those growing with 3 other Puccinellia plants (0.09 to $0.28 \mathrm{~g}$ in $+3^{\circ} \mathrm{C}, 0.29$ to $0.39 \mathrm{~g}$ in enriched $\mathrm{CO}_{2}$ ). This indicates interspecific competition, with Spartina the superior competitor.

The reason can be seen in the different patterns of response of the 2 species (Fig. 3). Spartina responded to both elevated temperature and $\mathrm{CO}_{2}$ enrichment mainly by an increase in below-ground growth, which includes rhizome production. The significant interaction with density reflects the differences in resources available for growth below ground in the 2 pot sizes. By contrast, Pucinellia's response to higher temperatures and to $\mathrm{CO}_{2}$ enrichment was mainly to increase the above-ground production. Root growth in Puccinellia is affected by $\mathrm{CO}_{2}$ and temperature but is also restricted by below-ground competition with Spartina. These patterns can be seen in both the overall mean values of individual plant biomass (Fig. 3a) and also in the means for plants in pure stands at low density (Fig. 3b). The latter diagram indicates that the relatively poor performance of Spartina in the ++ treatment was a real effect and not one resulting solely from competition with Puccinellia, which did significantly reduce Spartina shoot weight.

The number of flowering tillers, which may be regarded as a measure of potential seed production, was remarkably unaffected by treatment in Spartina, and only by density (positively, with significantly more 


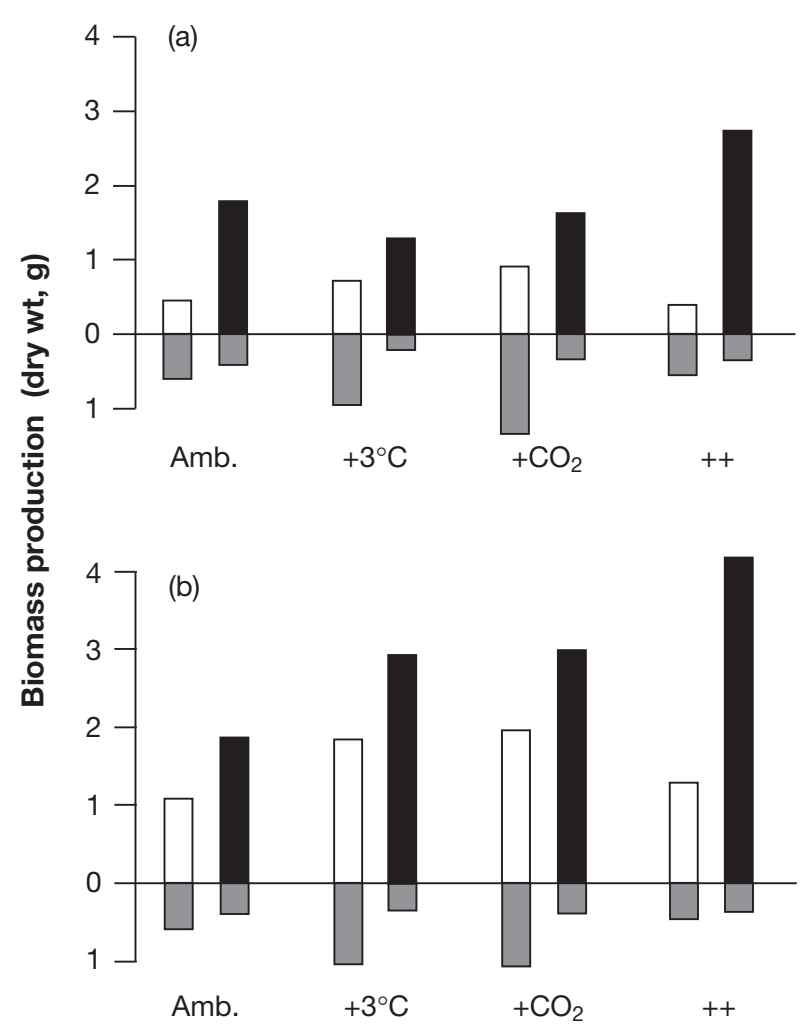

Fig. 3. Biomass production in solardome competition experiment, (a) averaged over all conditions, and (b) in pure stands at low density. Data are mean individual plant biomass at (a) harvest for above-ground material in Spartina (open columns) and Puccinellia (filled columns) with below-ground biomass (shaded) below the zero line. Treatments (Amb., $+3{ }^{\circ} \mathrm{C},+\mathrm{CO}_{2}$, $++)$ as described in text and Table 1

flowering tillers in the smaller pots) and intraspecific competition in Puccinellia. Although seed output may be an important aspect of competitive interactions in many species, field evidence (see Section 2.1 above) suggests that vegetative competition is the major force controlling interactions between these 2 perennial grasses.

\subsection{Discussion}

A comparison of plant growth in ambient conditions with that in elevated temperature plus enriched $\mathrm{CO}_{2}$ provides broad agreement with model predictions (Long 1990) of increased growth. The mean biomass of individual Puccinellia plants increased by $\sim 100 \%$ in pure stands compared to a predicted increase of $~ 80 \%$ in cumulative net primary production in the model; although these figures are not exactly the same, they are encouragingly similar. Although mean yield increases for Spartina in pure stands of 72 and $95 \%$ in elevated temperature and $\mathrm{CO}_{2}$ respectively, equate well with the $62 \%$ increase in primary production predicted by the model, the very small increase compared with ambient (5\%) in plants grown in pure stands is an unexpected result (Fig. 3b).

The response of Puccinellia to enriched $\mathrm{CO}_{2}$ is in line with that found in other empirical studies of $\mathrm{C}_{3}$ species (see review by Bazzaz 1990). Its increased production in elevated temperatures, in pure stands at low density, may reflect the benefit from increased earlyseason leaf growth, as it would reach the point where it could intercept $30 \%$ of the incoming radiation some 35 d earlier (Long 1990). Spartina's response to elevated temperature is also in accordance with predictions and other experiments (Long \& Woolhouse 1978, Dunn et al. 1987) but the increased production, particularly below-ground, in enriched $\mathrm{CO}_{2}$ is perhaps surprising, and at variance with earlier work. For example, the $\mathrm{C}_{4}$ grasses Spartina patens and Distichlis spicata showed no significant response to $\mathrm{CO}_{2}$ enrichment in open top chambers in a Chesapeake Bay saltmarsh, whereas the $\mathrm{C}_{3}$ Scirpus olneyii gained significantly more above- and below-ground biomass (Curtis et al. 1989).

It is important, however, to consider not only the effects of competitive interactions, both inter- and intra-specific, but also the interactions between elevated temperature and $\mathrm{CO}_{2}$ and other factors influencing plant growth, including nutrient supply and water relations. For example, Owensby et al. (1993), whose study of a prairie ecosystem also demonstrated that elevated $\mathrm{CO}_{2}$ increased the production of $\mathrm{C}_{4}$ grass species, suggest that increased water-use efficiency associated with partial stomatal closure will be an important mechanism for increasing productivity in natural ecosystems with periodic moisture stress-and will have an impact irrespective of photosynthetic pathway. They concluded that because of this, the $\mathrm{C}_{4}$ perennial tallgrass dominants of these prairies would continue to dominate and, perhaps unless continuous grazing was applied, there would be no shift in competitive advantage in favour of the $\mathrm{C}_{3}$ grasses.

Differences in canopy architecture (Wetzel \& van der Valk 1998), the timing of the main phase of competition (Wray \& Strain 1987), and the responses induced by varying plant density (Wayne et al. 1999) are among the most important factors influencing the outcome of plant competition. In this study, yield at harvest after 1 yr growth provides a useful snapshot of the interactions of the 2 species, demonstrating the trends in relation to treatment discussed above, and suggesting that competition is mediated by plant height and rhizome development. The generalised ANOVA provides a rigorous test of treatment effects (with only $1 \mathrm{df}$ ) and competition (with $3 \mathrm{df}$ ) pooling all plants according to treatment. It reveals also the importance of density 
and, with the careful initial matching of plant size, thus avoids most of the weaknesses of replacement series designs (Law \& Watkinson 1987, Snaydon 1991, Gibson et al. 1999). However, the experiment has limitations due to its size and the fact that only a final harvest was possible, missing the dynamics of the species' interactions. These should be borne in mind when extrapolating to future climate change scenarios.

\section{CONCLUSIONS}

Bazzaz (1990) and, more recently, Dukes \& Mooney (1999) point out that it is risky to make predictions about the impact of climate change on plant species, particularly on the basis of their photosynthetic pathway or their response to $\mathrm{CO}_{2}$, in the absence of other species. Individual species' responses may be highly modified by the communities to which they belong and by changes in resource levels, the activities of herbivores and pathogens, and a complex of other interactions. Despite this, we believe that the pioneer saltmarsh system presents us with one of the best chances of making a broadly accurate prediction. It is relatively simple, being dominated by 2 grass species whose competitive interactions largely occur at the vegetative phase, and one of the species is demonstrably limited by climate. Furthermore, dispersal, about which major assumptions usually have to be made in modelling and predicting climate-driven shifts in species' range, is not a major issue. Both species are widely dispersed by tides and have small colonies in northern estuaries to act as foci for invasive spread. Finally, although studies have separately demonstrated the complexity of ecosystem-level responses to both elevated temperature (Chapin et al. 1995, Harte \& Shaw 1995) and enriched $\mathrm{CO}_{2}$ (Curtis et al. 1989, Owensby et al. 1993), in this simpler system we have been able to assess the impact of both factors separately and in concert.

On a local scale, the outcome of competition between Spartina and Puccinellia will clearly depend on the balance between increased $\mathrm{CO}_{2}$ concentration and temperature, and on the rates at which these change. Whilst an average global warming of 1 to $3.5^{\circ} \mathrm{C}$ over the next century may be predicted as a result of an increase in greenhouse gases, this is likely to vary spatially and is predicted to be higher in northern latitudes in winter (Houghton 1996). In general, we may expect Spartina to extend its range northwards from $57^{\circ} \mathrm{N}$, in the lowest zones of saltmarsh, as temperatures and $\mathrm{CO}_{2}$ levels rise. In those parts of its elevational niche where factors related to tidal submergence prevent the establishment and growth of Puccinellia, the increased biomass, and especially the increase in below-ground root and rhizome production, should allow Spartina to expand northwards wherever suitable sedimentary environments occur. However, we predict that the competitively superior Puccinellia will continue to replace it at appropriate elevations. Further, the additive effect of elevated temperature and $\mathrm{CO}_{2}$ enrichment on Puccinellia performance, coupled with the unexpectedly small increase in Spartina growth in such conditions, suggests that Puccinellia may invade Spartina swards at an earlier successional stage in these northern marshes. The increased competitive superiority of Puccinellia under the new regime of both higher temperatures and $\mathrm{CO}_{2}$ enrichment will also enable it to extend its elevational limits further downshore in existing marshes at latitudes below $57^{\circ} \mathrm{N}$.

The net outcome of Spartina's enhanced ability to invade northwards, and Puccinellia's ability to replace it earlier in the succession, is likely to be the northward development of saltmarshes with lower elevational limits than at present. The extent of such pioneer zones will depend on local changes in precipitation regimes, about which global circulation models are as yet too general to be helpful, because high rainfall, mainly through its effect on salinity and particularly on Atlantic coasts, empowers a downshore shift in saltmarsh zones (Adam 1990). Whilst also depending on changes in a number of ecosystem processes such as nutrient dynamics, other aspects of climate change that will be of critical importance in determining the spread of saltmarsh are the impact of rising relative sea level and its relationship on a local scale to sediment availability and accretion rate, and changes in storm frequencies and/or wind direction (e.g Hulme \& Jenkins 1998). Interestingly, these largely non-biological variables are proving equally difficult to predict in detail.

Acknowledgements. The authors are grateful to L. Jones, T. Ashenden and the staff of ITE (now CEH) at the Bangor solardomes facility for maintenance of the competition experiment, and to R.T. Clarke for statistical analysis. The research was, in part, supported by an award to A.J.G. under the UK Natural Environment Research Council's thematic programme on climate change-TIGER (Terrestrial Initiative in Global Environmental Research) 4.2a, award number T03087f6.

\section{LITERATURE CITED}

Adam P (1990) Saltmarsh ecology. Cambridge University Press, Cambridge

Ashenden TW, Stirling CM, Rafarel CR (1994) Responses of grasses to changes in $\mathrm{CO}_{2}$ and temperature. Report of the Institute of Terrestrial Ecology. 1993-1994. Natural Environment Research Council, Swindon, p 44-47

Bazzaz FA (1990) The response of natural ecosystems to the rising global $\mathrm{CO}_{2}$ levels. Annu Rev Ecol Syst 21:167-196

Brown SL (1998) Sedimentation on a Humber saltmarsh. In: Black KS, Paterson DM, Cram A (eds) Sedimentary processes in the intertidal zone. Geol Soc Lond Spec Pub 139, p 69-83 
Chapin FS, Shaver GR, Giblin AE, Nadelhoffer KJ, Laundre JA (1995) Responses of Arctic tundra to experimental and observed changes in climate. Ecology 76:694-711

Charman K (1990) The current status of Spartina anglica in Great Britain. In: Gray AJ, Benham PEM (eds) Spartina anglica - a research review. HMSO, London, p 11-14

Curtis PS, Drake BG, Whigham DF (1989) Nitrogen and carbon dynamics in $\mathrm{C}_{3}$ and $\mathrm{C}_{4}$ estuarine marsh plants grown under elevated $\mathrm{CO}_{2}$ in situ. Oecologia 78:297-301

De Wit CT (1960) On competition. Verslagen van Landbouwkundige Onderzoekingen 66:1-82

Dukes JS, Mooney HA (1999) Does global change increase the success of biological invaders? TREE 14:135-139

Dunn R, Long SP, Thomas SM (1981) The effects of temperature on the growth and photosynthesis of the temperate $\mathrm{C}_{4}$ grass Spartina townsendii. In: Grace J, Ford ED, Jarvis PG (eds) Plants and their atmospheric environment. Blackwell, Oxford, p 301-311

Dunn R, Thomas SM, Keys AJ, Long SP (1987) A comparison of the growth of the $\mathrm{C}_{4}$ grass Spartina anglica with the $\mathrm{C}_{3}$ grass Lolium perenne at different temperatures. J Exp Bot 38:433-441

Gibson DJ, Connolly H, Hartnett DC, Weidenhamer JD (1999) Designs for greenhouse studies of interactions between plants. J Ecol 87:1-16

Gray AJ (1986) Do invading species have definable genetic characteristics? Phil Trans R Soc Lond B 314:655-674

Gray AJ (1992) Saltmarsh plant ecology: zonation and succession revisited. In: Allen JRL, Pye K (eds) Saltmarshes: morphodynamics, conservation and engineering significance. Cambridge University Press, Cambridge, p 63-79

Gray AJ (1995) Saltmarsh ecology. In: A guide to the management and understanding of saltmarshes. Environment Agency R\&D Note 324. Environment Agency, Bridgwater, p 73-100

Gray AJ, Raybould AF (1997) The history and evolution of Spartina anglica in the British Isles. Proceedings 2nd International Spartina Conference, Washington State University, Olympia, p 13-16

Gray AJ, Scott R (1977) Puccinellia maritima (Huds.) Parl. Biological flora of the British Isles. J Ecol 65:699-716

Gray AJ, Marshall DF, Raybould AF (1991) A century of evolution in Spartina anglica. Adv Ecol Res 21:1-62

Gray AJ, Warman EA, Clarke RT, Johnson PJ (1995) The niche of Spartina anglica on a changing coastline. In: Coastal zone topics: process, ecology and management 1 , p 29-34

Gray AJ, Raybould AF, Brown SL (1997) The environmental impact of Spartina anglica: past, present and predicted. Proceedings 2nd International Spartina Conference, Washington State University, Olympia, p 39-45

Harte J, Shaw R (1995) Shifting dominance within a montane vegetation community: results of a climate-warming experiment. Science 267:876-880

Houghton JT (ed) (1996) Climate change 1995: the science of climate change: contribution of Working Group 1 to the Second Assessment Report of the Intergovernmental
Panel on Climate Change. Cambridge University Press, Cambridge

Hulme M, Jenkins GJ (1998) Climate change scenarios for the UK: scientific report. UKCIP Technical Report No. 1, Climate Research Unit, Norwich

Lambert JM (1964) The Spartina story. Nature 204:1136-1138

Law R, Watkinson AR (1987) Response-surface analysis of two-species competition: an experiment on Phleum arenarium and Vulpia fasciculata. J Ecol 75:871-886

Long SP (1983) $C_{4}$ photosynthesis at low temperatures. Plant Cell Environ 6:345-363

Long SP (1990) The primary production of Puccinellia maritima and Spartina anglica: a simple predictive model of response to climate change. In: Beukema JJ, Wolff WJ, Brouns JJWM (eds) Expected effects of climatic change on marine coastal ecosystems. Kluwer, Dordrecht, p 33-39

Long SP, Woolhouse HW (1978) The response of net photosynthesis to light and temperature in Spartina townsendii, a $\mathrm{C}_{4}$ species from a cool temperate climate. J Exp Bot 29:803-814

Long SP, Dunn R, Jackson D, Othman SB, Yaakub MH (1990) The primary productivity of Spartina anglica on an East Anglian estuary. In: Gray AJ, Benham PEM (eds) Spartina anglica-a research review. HMSO, London, p 34-38

Marchant CJ (1967) Evolution in Spartina (Gramineae). I. History and morphology of the genus in Britain. Bot J Linn Soc 60:1-24

Marchant CJ (1968) Evolution in Spartina (Gramineae). II. Chromosomes, basic relationships and the problem of the S. townsendii agg. Bot J Linn Soc 60:381-409

Owensby CE, Coyne PI, Ham JM, Aven LM, Knapp AK (1993) Biomass production in a tallgrass prairie ecosystem exposed to ambient and elevated $\mathrm{CO}_{2}$. Ecol Appl 3:644-653

Ranwell DS (1967) World resources of Spartina townsendii (s.l.) and economic use of Spartina marshland. J Appl Ecol 4:239-256

Raybould AF, Gray AJ, Lawrence MJ, Marshall DF (1991a) The evolution of Spartina anglica C E Hubbard: origin and genetic variability. Biol J Linn Soc 43:111-126

Raybould AF, Gray AJ, Lawrence MJ, Marshall DF (1991b) The evolution of Spartina anglica C E Hubbard: variation and status of the parental species in Britain. Biol J Linn Soc 44:369-380

Snaydon RW (1991) Replacement or additive designs for competition studies? J Appl Ecol 28:930-946

Scholten MCJ, Rozema J (1990) The competitive ability of Spartina anglica on Dutch saltmarshes. In: Gray AJ, Benham PEM (eds) Spartina anglica-a research review. HMSO, London, p 39-47

Wayne, PM, Carnelli, AJ, Connolly J, Bazzaz FA (1999) The density dependence of plant responses to elevated $\mathrm{CO}_{2}$. J Ecol 87:183-192

Wetzel, PR, van der Valk AG (1998) Effects of nutrient and soil moisture on competition between Carex stricta, Phalaris arundinacea and Typha latifolia. Plant Ecol 138:179-190

Wray SM, Strain BR (1987) Interaction of age and competition under $\mathrm{CO}_{2}$ enrichment. Funct Ecol 1:145-149

Proofs received from author(s): June 29, 2001 